\title{
ISKANJE DODATNIH VIROV ZASLUŽKA NA PODEŽELJU: PRIMER DOPLONILNIH DEJAVNOSTI NA KMETIJAH V SLOVENIJI
}

Irma Potočnik*

Izvleček

Dopolnilne dejavnosti niso novost na slovenskih kmetijah, tako kot tudi ne njihov prispevek k skupnemu dohodku kmečkega gospodarstva, vendar pa je mogoče $v$ zadnjem desetletju zaslediti njihov razcvet $v$ raznovrstnosti in obsegu. Prispevek analizira vzroke za pospešen razvoj dopolnilnih dejavnost, najnovejšo regulativo in posreduje geografski vidik dopolnilnih dejavnosti (s študijo primera na kmetijah izbranih območij Ljubljanske kotline).

Ključne besede: dopolnilne dejavnosti na kmetiji, podeželje, kmetijstvo, Slovenija.

\section{DIVERSIFICATION OF INCOME IN RURAL AREAS/ THE ISSUE OF SUPPLEMENTARY ACTIVITIES ON FARMS IN SLOVENIA}

\begin{abstract}
The issue on supplementary activities on farms as also their impact on farm income does not represent a new phenomena in Slovenia, but a new flourishing wave is to be seen in the last decade in the area of diversification and extent. The article analyses the motives of accelerated development of supplementary activities, reveals the newest legislation and through the case study of farms in Ljubljana basin indicates the geographical aspect of supplementary activities on farms.
\end{abstract}

Key words: supplementary activities on farm, rural areas, agriculture, Slovenija.

\footnotetext{
* mag. Irma potočnik, Univerza v Ljublani, Filozofska fakulteta, Oddelek za geografijo, Aškerčeva 2, SI - 1000 Ljublana, Slovenija, e-pošta; irma.potocnik@ff.uni-lj.si.
} 


\section{Uvod}

Dopolnilne dejavnosti na kmetijah $v$ Sloveniji so $v$ zadnjih letih predmet različnih in številnih razprav. Če želimo predstaviti geografski vidik dopolnilnih dejavnosti na slovenskih kmetijah, je potrebno izpostaviti naslednje trditve.

- Problematika dopolnilnih dejavnosti na kmetijah je v Sloveniji slabo raziskana, saj ne poznamo niti vseh pojavnih oblik in obsega, pa tudi ne ekonomskih razsežnosti.

- Iz državnega proračuna ni jasno razvidno, koliko denarja se namenja dopolnilnim dejavnostim na kmetiji.

- Zaenkrat še ne obstaja informacijski sistem, ki bi sistematično vključeval kmetije, ki se ukvarjajo z dopolnilnimi dejavnostmi ("prešteti nepreštevno«?).

- Ključna ovira za razvoj dopolnilnih dejavnosti na kmetijah je pomanjkanje, nedodelanost ali neustreznost normativnih aktov, ki urejajo tovrstne dejavnosti (zlasti predpisi o predelavi in prodaji pridelkov na kmetijah).

- Kmetje, ki imajo interes za izvajanje dopolnilnih dejavnosti, imajo pomanjkljivo specifično izobrazbo.

Podatki, uporabljeni v prispevku, so zbrani na osnovi virov, posredovanih s strani Ministrstva za finance, Ministrstva za kmetijstvo, gozdarstvo in prehrano (MKGP), Statističnega urada Republike Slovenije (SURS) in uradnih listov. Ker trenutno še ne obstaja register kmetij v Sloveniji, ki se ukvarjajo z dopolnilno dejavnostjo ( $v$ nastajanju), ni mogoče dobiti natančnih podatkov o številu in vrstah le-teh. Okvirne številčne podatke nam je posredoval pristojen organ za dopolnilne dejavnosti na MKGP. Junija 2000 je bil izveden popis kmečkih gospodarstev, katerega prvi rezultati so že dostopni, podrobnejše analize rezultatov popisa (med njimi tudi o nosilcih in vrstah dopolnilnih dejavnosti) pa bodo dostopne šele po zaključku redakcije zbornika. Zaradi pomanjkanja potrebnih podatkov je bila izvedena anketa na kmetijah v osrednjem delu Slovenije na reprezentativnem vzorcu 237 kmetij. 


\section{Opredelitev pojma}

V slovenski strokovni literaturi (geografi, agronomi, sociologi) ni bilo enotnega poimenovanja dopolnilnih dejavnosti na kmetiji ${ }^{1}$.

S problemom terminologije se je ukvarjala Barbičeva, ki je dejavnosti, katere predstavljajo različne vire dohodkov zunaj dohodkov iz kmetijstva in gozdarstva, najprej nameravala poimenovati kot "nekmetijske" dejavnosti (kmečkih) gospodinjstev in podeželskih skupnosti, vendar je ugotovila, da so številne gospodarske dopolnilne dejavnosti predvsem kmečkih gospodinjstev neposredno in posredno vezane na primarno kmetijsko proizvodnjo. Tako je poleg izraza "nekmetijski viri dohodkov" uporabila tudi izraz "obkmetijski viri dohodkov" (kmečkih) gospodinjstev in podeželskih lokalnih skupnosti, od katerih vsak posamično in vsi skupaj v večjem ali manjšem obsegu dopolnjujejo dohodek iz primarne kmetijske dejavnosti znotraj vsake podeželske skupnosti² (Barbič, 1995, 133).

Geografska stroka opredeljuje dopolnilne dejavnosti na kmetiji kot dejavnosti, ki $v$ gospodarsko razvitih deželah predvsem na območjih z majhnimi kmetijami omogočajo doseganje paritetnega dohodka (Kladnik, 1999, 17), v manj razvitih deželah, kjer so storitvene dejavnosti slabše razvite, pa v prvi vrsti zagotavljajo vsestransko delovanje podeželske skupnosti.

Podobne vsebinske opredelitve dopolnilnih dejavnosti so tudi v angleški literaturi (Illbery, Bowler, 1998, 77, 78), kjer člani kmečkega gospodinjstva z dopolnilno dejavnostjo pridobivajo dohodek iz virov na kmetiji in/ali izven kmetije kot dodatek dohodku, pridobljenem primarno iz kmetijstva.

Kovačič označuje kot dopolnilne dejavnosti tiste gospodarske dejavnosti kmečkin gospodinjstev, ki temeljijo na virih kmetije in na domači obrti in imajo za cilj zagotoviti polno izrabo delovnih moči ter dopolnilni dohodek (Kovačič, 2000, 112).

Nekaj časa sta se v Sloveniji uporabljala celo dva izraza (dopolnilne in dodatne dejavnosti na kmetiji), kar je ustvarjalo terminološke nejasnosti. Zakon o kmetijstvu (ZK, sprejet leta 2000) uzakonja izraz dopolnilna dejavnost na kmetiji za dejavnost, ki je povezana s kmetijstvom oz.

$1 \mathrm{~V}$ angleškem jeziku je sopomenka iskati $\mathrm{v}$ izrazih pluriactivty in diversification of farm income; v nemškem jeziku Direktvermarktung in vente directe $v$ francoskem.

2 Tako povezovanje kmetijskih in nekmetijskih virov dohodkov pa nikakor ne zanika dejstva, da se $v$ številnih podeželskih lokalnih skupnostih povečuje število posameznikov, gospodinjstev in malih podjetij, ki pridobivajo dohodek iz povsem nekmetijskih dejavnosti. 
gozdarstvom, ki se opravlja na kmetiji in omogoča kmetiji boljšo rabo njenih proizvodnih zmogljivosti ter delovne sile družinskih članov (ZK, 2000, čl. 67, 18) ${ }^{3}$.

Dopolnilne dejavnosti so v Sloveniji slabo preučene. Različni avtorji (zlasti V. Klemenčič, M. M. Klemeničič, Pak, Jeršič, Kladnik, Kovačič idr.) so poglobljeno in z genetsko-perspektivnega vidika preučevali mešana oz. polkmečka gospodinjstva, ki so dohodek pridobivala tako iz kmetijske kot tudi iz (večinoma) neagrarne dejavnosti. Prva interdisciplinarno zasnovana in poglobljena raziskava dopolnilnih dejavnosti sega v sredino 80. let 20. stoletja (Barbič, Kladnik, Rupena-Osolnik, Kovačič idr., 1984). Avtorji so opredelili različne dejavnike, ki vplivajo na nastanek in razvoj dopolnilnih dejavnosti, ter analizirali njihove specifične značilnosti (razporeditev preko leta, nosilci, zvrsti). S kompleksno analizo 2052 kmetij ${ }^{4}$ v 13 slovenskih občinah in z različnimi kvantitativnimi kazalci (npr. korelacija med interesom za uvajanje in razširitev dopolnilnih dejavnosti in spolom gospodarja ter njegovo starostjo ipd.) so pridobili zanimive ugotovitve o razširjenosti, perspektivah in vlogi dopolnilnih dejavnosti v celotnem prihodku kmetije.

Z nadgradnjo omenjene raziskave je Barbičeva sredi 90. let 20. stoletja analizirala razloge za uvajanje dopolnilnih dejavnosti na kmetiji, prepoznala nekaj njihovih pojavnih oblik ter definirala skupine nosilcev dejavnosti (posameznik/podjetnik, kmečko gospodinjstvo, podeželska skupnost) in načela, ki le-te vodijo in usmerjajo (trajnostnost, podjetništvo, partnerstva). Primerjalno je podala glavne značilnosti dopolnilnih dejavnosti v nekaterih evropskih državah ter označila potencialno vlogo dopolnilnih dejavnosti v prihodnosti (Barbič, 1995).

S predvidenimi učinki dopolnilnih dejavnosti v prostoru se je ukvarjala interdisciplinarna skupina strokovnjakov v sklopu projekta Trajnostno regionalno razvojno načrtovanje ${ }^{5}$. Marušič je izdelal matrike s simuliranimi potencialnimi pozitivnimi in negativnimi učinki, ki bi sledili izbiri in izvedbi prioritet razvojnih programov v Sloveniji (npr. prestruktiriranje kmetijstva, celostni razvoj podeželja: podpore ekonomski raznovrstnosti podeželja, inovativni programi za razvoj podeželskih ekonomij) ob upoštevanju določenih ciljev na področju okolja in trajnostnega regionalnega razvoja (Marušič, 2000, 50-57).

3 Ker je opredelitev dopolnilnih dejavnosti v ZK zasnovana po mednarodni terminologiji, bo le-ta zaradi boljše primerljivosti uporabljena tudi v prispevku.

4 Raziskava je vključevala vsa kmetijska gospodarstva, ki so imela 1 ha ali več obdelovalne zemlje.

5 Sodelavci strokovne skupine so pripravili metodološka priporočila za strateško presojo vplivov na okolje njihovim potencialnim uporabnikom na državni in lokalni ravni. 
Običajno pa večina avtorjev, ko razpravlja o možnostih bodočega razvoja kmetijstva in podeželja, kot obvezno (pod)poglavje vključuje kratko osebno videnje dopolnilnih dejavnosti. Zanimivo je, da tudi s strani MKGP ni bila izvedena raziskava o prostorskih, ekonomskih in socialnih učinkih dopolnilnih dejavnosti na kmetiji.

V zadnjih petih letih se je kar precej študentov dodiplomskega študija 6 ukvarjalo s problematiko dopolnilnih dejavnosti na mikro lokalnem nivoju (na primeru posamezne kmetije ali izbranega naselja) predvsem z vidika njihove gospodarske uspešnosti.

Najnovejše zasnove strategije razvoja kmetijstva in dopolnilnih dejavnosti, pripravljene po naročilu lokalnih skupnosti (npr. Kovačič, Udovč, Fabijan, Perpar idr., 2000; Potočnik, 2001 itn.), posredujejo grobe projekcije razvoja kmetijstva in dopolnilnih dejavnosti, analize nekaterih ekonomskih parametrov tega razvoja, predloge programa ukrepov in (poredko) konkretne projekte za spodbujanje in usmerjanje razvoja kmetijstva in dopolnilnih dejavnosti.

Zato so ugotovitve o dopolnilnih dejavnostih večinoma plod parcialnih in prostorsko omejenih raziskav, ki kar kličejo k široko zasnovani in podrobni analizi tovrstnih dejavnosti $v$ Sloveniji ter primerjavo $s$ podobnimi študijami v Evropi. Predvsem v Avstriji se t.i. regionalni menedžerji v posameznih regijskih agencijah ukvarjajo s praktičnimi vidiki različnih dopolnilnih dejavnosti (npr. Buschenschenke na Koroškem).

\section{Financiranje dopolnilnih dejavnosti na kmetiji}

Financiranja dopolnilnih dejavnosti na kmetiji v Sloveniji ni enostavno razbrati, saj se tovrstne dejavnosti financirajo iz različnih virov.

Pomen slovenskega kmetijstva se $v$ gospodarskem smislu zmanjšuje: kmetijstvo letno ustvarja 0,7 mlrd E, zaposluje 5,6 \% aktivnega prebivalstva (SL, 2000: 645) in ustvarja 4,3 \% BDP (SL, 2000, 679), izdatki za kmetijstvo v državnem proračunu v zadnjem desetletju naraščajo (od leta 1994 do 2001 so se štirikratno povečali; grafikon 1). Določen del dopolnilnih dejavnosti

\footnotetext{
5 Sodelavci strokovne skupine so pripravili metodološka priporočila za strateško presojo vplivov na okolje njihovim potencialnim uporabnikom na državni in lokalni ravni.

6 Zlasti na Biotehniški fakulteti, Oddelek za agronomijo.
} 
(predvsem predelava kmetijskih pridelkov) se financira iz proračuna MKGP. $\mathrm{V}$ proračunu tega ministrstva za leto 2001 (namenjenih 46.462.559.000 SIT ali 3,8 \% državnega proračuna; UL RS, 32/2001) ni mogoče natančno razbrati, koliko denarja država namenja razvoju dopolnilnih dejavnosti. Iz navedenih (nekaterih) proračunskih postavk (tabela 1) je mogoče sklepati, da gre denar tudi za uvajanje in razvoj dopolnilnih dejavnosti na kmetijah.

Grafikon 1: Denarni izdatki iz državnega proračuna, namenjeni kmetijstvu, gozdarstvu in ribištvu od leta 1994 do 2001.

Fig. 1: Budget Expenses for Agriculture, Forestry and Fishery in the period 1994-2001.

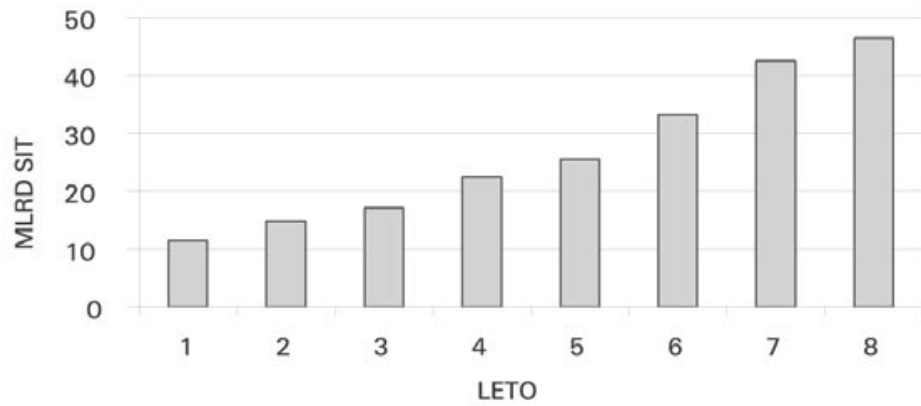

Opomba: $1=$ leto $1994, \ldots, 8=$ leto 2001.

Vir/Source: Ministrstvo za finance; UL RS, 32/2001.

Del sredstev kmetje dobijo tudi s strani Ministrstva za gospodarstvo, saj se domača obrt financira iz območnih obrtnih zbornic, kjer kmetje oz. nosilci dopolnilne dejavnosti tudi zaprosijo za dovoljenje, potrebno za opravljanje tovrstnih dejavnosti.

Obenem pa v zadnjem času zlasti organi lokalne samouprave, t.j. občine, z različnimi razpisi podpirajo ustanavljanje dopolnilnih dejavnosti (npr. javni razpis za subvencioniranje obrestne mere pri najetju kreditov za pospeševanja razvoja podjetništva, malega gospodarstva in kmetijstva $v$ občini Selnica ob Dravi (1. marca 2001). "Na področju kmetijstva se sredstva za subvencijo obrestne mere namenijo za graditev, prenovo in adaptacijo gospodarskih objektov kmetije, razširitev, posodobitev ter pridobivanje novih zmogljivosti $v$ osnovni kmetijski dejavnosti, razširitev, posodobitev ter pridobivanje novih zmogljivosti za dopolnilne dejavnosti na 
kmetiji, nakup zemljišč in izdelavo razvojnih programov. Za sredstva lahko zaprosijo zasebni kmetijski proizvajalci, ki so pokojninsko zavarovani kot kmetje, občani, ki izpolnjujejo pogoje za opravljanje dopolnilne dejavnosti na kmetiji, drugi občani, ki se ukvarjajo s kmetijstvom, prednost pa imajo kmetje, katerim kmetijstvo pomeni edini vir preživljanja ter kmetijske zadruge." 7

Tabela 1: Proračunska sredstva MKGP za leto 2001 (izbrane proračunske postavke).

Tab. 1: Selected budget items of Ministry for Agriculture, Forestry and Food for year 2001.

\begin{tabular}{|c|c|}
\hline PRORAČUNSKA POSTAVKA & VIŠINA SREDSTEV (v 000 SIT) \\
\hline razvoj podeželja & 1.073 .309 \\
\hline - obnova vasi & $(198.341)$ \\
\hline $\begin{array}{l}\text { - inovativni programi za razvoj podeželskih } \\
\text { ekonomij }\end{array}$ & (188.509) \\
\hline $\begin{array}{l}\text { - podpore ekonomski diverzifikaciji podeželja } \\
\text { (alternativni dohodkovni viri) }\end{array}$ & $(288.442)$ \\
\hline $\begin{array}{l}\text { - ukrepi prostorskega urejanja (razvoj } \\
\text { infrastrukture, povezane s kmetijstvom) }\end{array}$ & (398.017) \\
\hline $\begin{array}{l}\text { javni zavod Center za razvoj kmetijstva in } \\
\text { podeželja Jable }\end{array}$ & 89.209 \\
\hline SAPARD - tuja donacija & 685.476 \\
\hline SAPARD - lastna udeležba & 323.519 \\
\hline
\end{tabular}

Vir/Source: UL RS, 32/2001.

Opomba: vključena so tudi sredstva iz sledečih proračunskih postavk (Phare CFCU - Program prekomejnega sodelovanja z Avstrijo, Italijo; sofinanciranje pomembnih nacionalnih projektov kmetijstva; slovenski kmetijski okoljski program; podpore tržnim organizacijam pridelovalcev; programi podpor za prestrukturiranje in prenovo kmetijske proizvodnje; javna kmetijska svetovalna služba; sofinanciranje kmetijskega izobraževanja, podpora kmetijsko znanstveno-raziskovalnemu delu ipd.).

\footnotetext{
7 Razpis določa, da se bodo "prednostno sredstva podeljevala po sledečem vrstnem redu: razvoj družinske kmetije (glede na starostno strukturo, velikost kmetije in možnost dodatne zaposlitve), kmetije, ki izvajajo dopolnilne dejavnosti, investicije v zadružništvu, izvajanje programov CRPOV, PHARE in SAPARD; http://www.izit.si/muv/2001/predpisi/90.html). Podoben razpis za dodeljevanje dolgoročnih kreditov pod ugodnejšimi pogoji (sodelovanje z bančnimi institucijami) je objavila npr. občina Ormož za "gradnjo in obnovo objektov za dodelavo, skladiščenje, predelavo kmetijskih pridelkov ter pripadajoče opreme za dopolnilne dejavnosti na kmetiji"; http://www.nkbm.si/html/poslovanje/razpisi/ormoz_posojila.html ).

8 Od 520 mioŌ letno, ki jih bo EU v programskem obdobju 2000-2006 namenjala državam kandidatkam, bo Slovenija prejemala letno 6,3 mio E. Slovenija se je odločila, da bo iz sredstev Sapard financirala štiri ukrepe (za razvoj dopolnilnih dejavnosti bo namenjenih 13\% sredstev, t.j. 1,33 mio E; Seminar, 2001).
} 
Z akreditacijo Agencije za kmetijske trge in razvoj podeželja (novembra 2001) bo Slovenija upravičena do koriščenja sredstev Evropske Unije Sapard (posebni predpristopni program za kmetijstvo in razvoj podeželja), kjer je posebna postavka namenjena (so)financiranju dopolnilnih dejavnosti na kmetiji ${ }^{8}$.

\section{Vzroki za razvoj dopolnilnih dejavnosti}

Razprave o dopolnilnih virih dohodkov kmečkih gospodarstev in podeželskih lokalnih skupnosti ni mogoče začeti brez opredelitve multifunkcijske vloge vloge kmetijstva. Kljub nespornemu dejstvu, da zagotavlja človeštvu življenjsko potrebne proizvode (prehranska varnost), kmetijska dejavnost kmetom ne zagotavlja ustrezno močnega gospodarskega položaja (paritetnega dohodka, kar je tudi eden izmed vzrokov za intervencije v kmetijstvo). Če ekonomskim dodamo še socialno (zagotovljeno delo za kmečko prebivalstvo in na njem temelječa socialna varnost), okoljsko (ohranjanje poseljenosti, obdelanost kmetijskih zemljišč) in kulturno vlogo (ohranjanje naravne in kulturne dediščine), se zdi državna pomoč kmetijstvu v razumnem obsegu skoraj neizogibna. Razlogi, ki utemeljujejo potrebo po državni finančni podpori kmetijstvu, veljajo tudi za meddržavne skupnosti. EU je do reforme skupne kmetijske politike $v$ začetku devetdesetih let 20. stoletja namenjala kmetijstvu velike subvencije in ustvarila organizem, ki ga ni mogla več obvladovati. Rešitve so začeli iskati v dopolnilnih dejavnostih, ki jih dodatno vzpodbuja potreba po varovanju virov in zagotavljanju pogojev za njihovo samoobnavljanje.

$\mathrm{Na}$ različne vrste dopolnilnih dejavnosti vplivajo različne kombinacije dejavnikov. Iskanje možnosti pridobivanja dohodka znotraj kmečkega gospodinjstva spodbujajo tako eksogeni (splošno pomanjkanje delovnih mest, nezaposlenost, povečan interes za življenje v čistem naravnem okolju, pestrost povpraševanja po pridelkih, izdelkih in surovinah ipd.) kot endogeni (razpoložljivi viri, individualna/družinska iniciativa) dejavniki. Ti spodbujajo sodobne tehnologije pridelave in predelave organskega živeža z oživljanjem in dopolnjevanjem tradicionalnih načinov pridelave in predelave kmetijskih pridelkov. Trg zanje je v številnih primerih kar na domačem dvorišču, kamor prihajajo pridelke in izdelke kupovat urbani prebivalci. Pogosto pa kmečka gospodarstva svoje pridelke in izdelke uporabljajo kot vnose lastnim dopolnilnim dejavnostim, predvsem turizmu na kmetiji ali drugim oblikam podeželskega turizma (vinske ceste, turistične poti, vinotoči, razne rekreacijske dejavnosti, zabavne in kulturne prireditve na podeželju, osmice). 
Slika 1: Vzroki za razvoj dopolnilnih dejavnosti.

Fig. 2: Motives for the Implementation of Supplementary Activities on Farms.

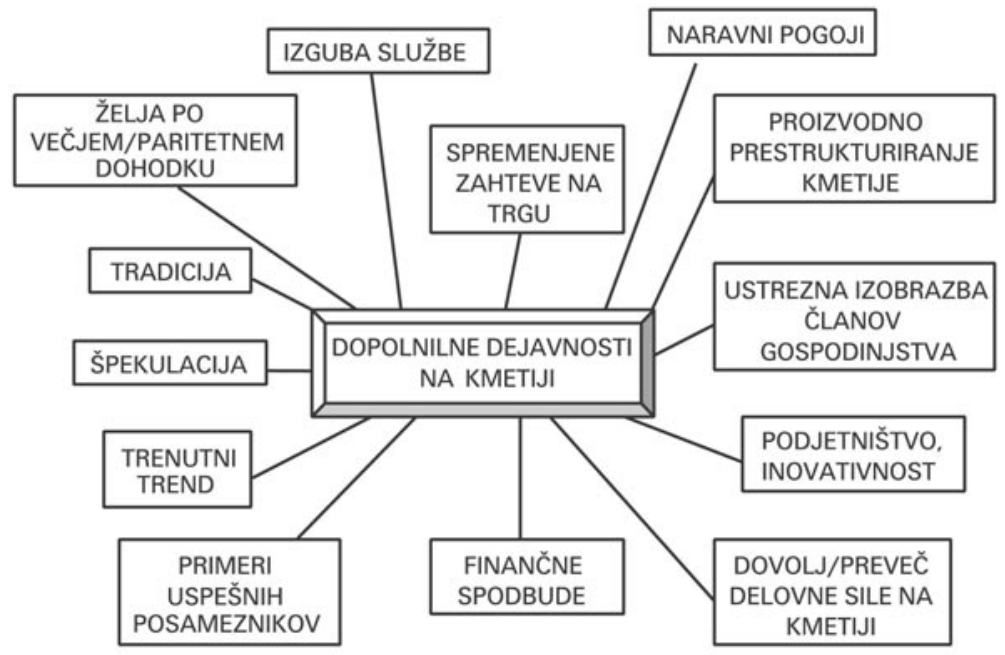

\section{Dopolnilne dejavnosti v Sloveniji in zakonodaja}

Po ZK dohodek iz kmetijske dopolnilne dejavnosti ne sme biti večji od dohodka iz kmetijske in gozdarske dejavnosti na kmetiji in ne sme presegati 1.2 povprečne plače na zaposlenega $v$ Republiki Sloveniji (na območjih z omejenimi dejavniki za kmetijstvo pa ne sme presegati 2.5 povprečne plače na zaposlenega v Republiki Sloveniji ${ }^{9}$ ).

Nosilec dopolnilne dejavnosti na kmetiji je fizična oseba (lastnik, zakupnik ali drugačen uporabnik kmetije), ki se za svoj račun ukvarja s kmetijsko dejavnostjo ter je za to ustrezno usposobljen.

Za opravljanje dopolnilne dejavnosti mora nosilec pridobiti dovoljenje, ki ga na njegovo zahtevo izda pristojna upravna enota oz. Obrtna zbornica Slovenije (če gre za dejavnosti domače ali umetne obrti). Če kmetija ne izpolnjuje z zakonom določenih pogojev, ji upravna enota lahko vzame dovoljenje za opravljanje dopolnilne dejavnosti na kmetiji.

\footnotetext{
9 Ne glede na navedeno zahtevo pa lahko Vlada Republike Slovenije za posamezne dejavnosti določi največji dovoljeni fizični obseg dopolnilne dejavnosti na kmetiji.
} 
MKGP vodi evidenco (še $v$ nastajanju) dopolnilnih dejavnosti na kmetiji (identifikacijski podatki o nosilcu dopolnilne dejavnosti na kmetiji, vrsta dopolnilne dejavnosti in drugi podatki o dejavnosti).

Najnovejšo regulativo (UL RS, 46/2001) na področju dopolnilnih dejavnosti predstavlja vladna uredba o vrsti, obsegu in pogojih za opravljanje dopolnilnih dejavnosti na kmetiji. Od sprejetja ZK do objave vladne uredbe o dopolnilnih dejavnosti je minilo celo leto; tako so se do julija 2001 kopičile vloge prijaviteljev dopolnilnih dejavnosti na kmetiji, vendar jim dovoljenja za opravljanje niso bila izdana, ker ni bilo ustreznega predpisa. V nekaterih delih je uredba zelo podrobna (naštevanje dejavnosti), verjetno pa se bo $v$ posameznih elementih izkazala tudi kot zelo neživljenjska (določene omejitve obsega), a kljub temu pomeni določen napredek na področju regulative glede dopolnilnih dejavnosti.

Sprejeti ZK zahteva kar nekaj podzakonskih aktov, ki pa s svojo objavo v uradnem listu običajno zamujajo. Velik problem tudi predstavljajo popravki ustreznih predpisov in vzpostavitev nadzornih služb (čeprav gre v številnih primerih le za prevzem predpisov in načinov kontrole kakovosti, ki so uveljavljeni v Evropi). Evropa preusmerja svoje doslej visokointenzivno kmetijstvo $v$ okolju prijaznejše in pospešeno sledi spremenjenemu okusu potrošnikov, ki vse bolj iščejo pridelke z znanim poreklom in zanesljivo kakovostjo. Resda cene "eko"10 pridelkov niso več dosti višje, vendar jih je laže prodati, kar je oz. bo v razmerah odprtega trga in hiperprodukcije vse pomembnejša tržna prednost. Naši predpisi s področja domače predelave kmetijskih pridelkov dejansko ne omogočajo razvoja te dejavnosti. Še vedno so naravnani izključno na razmere in pogoje industrijske predelave kmetijskih pridelkov, tako kot $v$ prejšnjem sistemu, ki domače predelave praktično ni dopuščal (podobno je tudi z določili za opravljanje turistične dejavnosti na kmetiji).

\section{Vrste dopolnilnih dejavnosti na kmetiji}

Posameznikom, kmečkim gospodarstvom in podeželskim lokalnim skupnostim so na voljo številne dejavnosti, v katerih se zaposlujejo oz. iz katerih pridobivajo dohodek. Čeprav so razlogi za iskanje alternativnih virov dohodkov kmečkega prebivalstva $v$ razvitih evropskih državah (kmetijska hiperpro-

10 Predpisi s področja ekološkega kmetovanja so bili sprejeti v začetku leta 2001. 
dukcija, visoka stopnja onesnaženosti prsti zaradi kmetijske proizvodnje, bolezni itd.) precej drugačni kot v Sloveniji (majhna in razdrobljena posest, razmeroma nizka kmetijska produktivnost), so (bile) nekmetijske okoliščine, katerim so (bili) kmetijski pridelovalci izpostavljeni (z izjemo preteklega socialističnega političnega sistema) podobne. Zato so tudi že uveljavljene in nove možnosti pridobivanja dohodka na podeželju precej podobne.

Gospodarske dejavnosti, ki temeljijo na kmetijstvu in drugih lokalnih virih, so se izkazale kot izredno učinkovite ne le kratkoročno, temveč tudi dolgoročno. Najbolj izrazit tovrstni primer je podeželski turizem. Kmetijstvo in podeželsko okolje predstavljata vir turizmu in hkrati od njega živita ali si vsaj izboljšujeta socio-ekonomski položaj. Samo z razvojem samostojnih gospodarskih dejavnosti lahko podeželske skupnosti zmanjšujejo svojo odvisnost od prispevkov kmetijske politike. Lokalno specifična proizvodnja (specifični proizvodi, lokalne rastlinske in živalske pridelovalne tehnologije, lokalna pridelava pridelkov) "ni več $v$ opoziciji $z$ internacionalizirano množično predelavo in potrošnjo. Povečana povezanost na globalni ravni ne odpravlja prisotnosti lokalnosti in lokalne identitete. Celo več, zdi se, da jo celo spodbuja" (Barbič, 1995, 138).

Kot nove možnosti gospodarskih dejavnosti kmečkih gospodinjstev se pojavljajo alternativne kmetijske pridelave in predelave kmetijskih pridelkov, ki hkrati pomenijo nove možnosti za zaposlovanje družinskih delovnih moči. Na nek način gre za procese, nasprotne tistim, ki so "silili" člane kmečkih družin, da so se zaposlovali zunaj kmetijstva.

Raziskave v Angliji in Walesu (Ilbery, Bowler, 1998, 77, 78) so pokazale, da imajo številne kmetije $\mathrm{z}$ dopolnilnimi dejavnostmi nekatere skupne značilnosti: običajno imajo večje kmetije višje neto dohodke, višjo stopnjo zadolženosti, gospodarji so mlajši (kot tisti, ki se niso odločili za dopolnilne dejavnosti), pridobili so si formalno kmetijsko izobrazbo, precejšen delež leteh ima otroke, ki želijo nadaljevati s kmetovanjem, kar je seveda stimulativno za razvoj dopolnilnih dejavnosti.

Tako kot organsko hrano je mogoče lokalno tržiti (zlasti v sklopu turizma) tudi različne izdelke domačih obrti: kot spominke in embalažo za družinske proizvode, kot dekorativne ali kot uporabne predmete, izdelane ročno in iz naravnih materialov. Njihovo izdelovanje temelji na lokalnih surovinah in družinskih delovnih močeh. Posebna prednost tovrstnih dopolnilnih dejavnosti pa je $v$ tem, da se je z njimi mogoče ukvarjati tudi takrat, ko ni 
kmetijskih/turističnih delovnih konic. Prav tako pa je izdelovanje izdelkov domače obrti moč ponuditi kot del turistične ponudbe kmetije, če se ta ukvarja s turizmom, ali pa kot del turistične ponudbe lokalne skupnosti. Ta vsaj v Sloveniji še ni izčrpala vseh možnosti.

Barbičeva je izpostavila naslednje oblike dopolnilnih dejavnosti: zaposlovanje zunaj kmetijstva, specifične pridelave in predelave kmetijskih pridelkov, (domače) obrti, majhna podjetja, pasivne vire dohodkov in turizem (Barbič, 1995, 134).

Kovačič razlikuje tri glavne skupine dopolnilnih dejavnosti (Kovačič, 2000, 112):

- dejavnosti, ki pomenijo oplemenitenje in finalizacijo temeljne proizvodnje na kmetiji (npr. predelava lesa in kmetijskih pridelkov, neposredno trženje osnovnih in predelanih proizvodov kmetije-prodaja na domu ali na kmečki tržnici);

- domače obrti in storitvene dejavnosti s proizvodnimi sredstvi kmetije (npr. storitve s kmetijskimi stroji, turistična dejavnost na kmetiji, suhoro barska dejavnost);

- delo na domu.

Vladna uredba (UL RS, 46/2001) pa predvideva sledeče vrste dopolnilnih dejavnosti na kmetiji:

- predelavo, obdelavo, dodelavo, zamrzovanje in pakiranje kmetijskih pridelkov in gozdnih sortimentov;

- prodajo predpisano označenih pridelkov in izdelkov okoliških kmetij na kmetiji;

- nabiranje, predelavo in prodajo gozdnih sadežev in zelišč;

- turizem na kmetiji;

- dejavnost, povezano s tradicionalnimi znanji na kmetiji (npr.: oglarstvo, tradicionalno krovstvo s slamo, skodlami in skriljem, peka v kmečki peči, izdelava drobnih galanterijskih izdelkov iz lesa, etnološke zbirke in etno loška dejavnost);

- pridobivanje in prodajo energije iz biomase;

- pridobivanje in prodajo energije iz vodnih, vetrnih idr. virov;

- storitve s kmetijsko in gozdarsko mehanizacijo in opremo (npr.: posek lesa, spravilo lesa iz gozda, delo s traktorjem in delo z drugo strojno opremo na kmetijah, oddajanje kmetijskih in gozdarskih strojev in opreme v najem, vzdrževanje cest in pluženje snega, servis in vzdrževanje zelenih površin, vzdrževanje kulturne krajine, žaganje lesa, stiskanje 
sadja, olja, mletje, sušenje sadja, ter druge storitve z obstoječo opremo in živalmi s kmetije: vožnja s sanmi, vozovi, jahanje konj);

- storitve delovne sile s kmetij, ki so povezane z znanji iz kmetijstva in gozdarstva;

- drugo izobraževanje na kmetijah, povezano z dejavnostjo na kmetiji;

- vrtnarstvo, čebelarstvo, perutninarstvo, ribogojstvo, gobarstvo, zeliščarstvo, sodelovanje v pridelavi in dodelavi semena in sadik, drevesničarstvo, trsničarstvo, reja divjadi;

- zbiranje in kompostiranje odpadnih organskih snovi.

Uredba določa tudi posebne pogoje za opravljanje dopolnilnih dejavnosti (npr. pri prodaji izdelkov okoliških kmetij je mogoče vključiti tudi pridelke in izdelke drugih kmetij do $50 \%$ vrednosti lastnih pridelkov in izdelkov; največ 600 litrov predelave mleka na dan, podobne omejitve obstajajo tudi pri predelavi mesa, peki kruha, potic ipd.; pri turistični dejavnosti na kmetiji uredba določa, da ima kmetija lahko največ 60 sedežev na izletniških kmetijah in vinotočih, 10 sob in dodatna skupna ležišča na kmetijah z nastanitvijo, določa tudi število ur, ki jih npr. lahko kmet opravlja kot storitve s kmetijsko in gozdarsko mehanizacijo itd.).

\section{Razširjenost dopolnilnih dejavnosti na kmetiji}

Ker zaenkrat še ne obstaja register kmetij, ki se ukvarjajo z dopolnilno dejavnostjo, je potrebno okvirne številčne podatke pridobiti s posrednimi viri: preko specializiranih sodelavcev kmetijske svetovalne službe in različnih tematskih publikacij, anket, oglasov na medmrežju, podatkov o številu članov posameznih združenj ipd. Ker do popisa kmetijskih gospodarstev v juniju 2000 še ni izšla uredba o vrstah dopolnilnih dejavnosti, se postavlja tudi vprašanje, kako natančni in uporabni bodo tovrstni podatki. S pomočjo posrednih virov je mogoče ugotoviti, da je v Sloveniji trenutno okrog 500 kmetij ${ }^{11}$, ki se uradno ukvarjajo z dopolnilno dejavnostjo: 420 jih je registriranih kot turistična kmetija ${ }^{12}$, osmica, vinotoč ali izletniška kmetija, preostali delež pa odpade na domače obrti in kmetijsko predelavo. Podatki so zbrani iz Kataloga turističnih kmetij (Slovensko podeželje: katalog turističnih kmetij, 1999), ki ga je izdalo Združenje turističnih kmetij Slovenije, ustanovljeno leta 1997, kjer so predstavljene turistične kmetije

$11 \mathrm{~V}$ bodoče naj bi te podatke zbirale upravne enote.

12 Ob koncu osemdesetih let 20. stoletja se je (predvsem zaradi neugodnih kreditov) s turistično dejavnostjo ukvarjalo le okrog 170 kmetij (Kovačič, 1994: 5). 
po različnih slovenskih pokrajinah ${ }^{13}$. Popis kmečkih gospodarstev je v letu 2000 zabeležil v Sloveniji 96.669 družinskih kmetij, torej se z dopolnilno dejavnostjo ukvarja $5 \%$ kmetij.

Tabela 2: Kmetijska izobrazba gospodarjev kmetij v Sloveniji leta 2000.

Tab. 2: Agricultural educational attainment of the farm holders in Slovenia in the year 2000 .

\begin{tabular}{|l|c|c|}
\hline STOPNJA KMETIJSKE IZOBRAZBE & ŠTEVILO OSEB & STRUKTURA (\%) \\
\hline SKUPAJ & 96.669 & 100,0 \\
\hline ni odgovora & 2.596 & 2.7 \\
\hline samo praktične izkušnje & 81.231 & 84,0 \\
\hline tečaji iz kmetijstva & 7.551 & 7,8 \\
\hline poklicna (dveletna) izobrazba & 1.688 & 1,7 \\
\hline poklicna (triletna) izobrazba & 1.187 & 1,2 \\
\hline srednja izobrazba & 1.700 & 1,8 \\
\hline višja izobrazba & 362 & 0,4 \\
\hline visoka strokovna izobrazba & 141 & 0,1 \\
\hline univerzitetna izobrazba & 177 & 0,2 \\
\hline podiplomska izobrazba & 36 & 0,0 \\
\hline
\end{tabular}

Vir/Source: Statistične informacije, št. 324/2000, 10.

Veliko oviro pri razširjanju dopolnilnih dejavnosti pomeni izrazito neugodna oz. slaba kmetijska (tudi splošna) izobrazba gospodarjev kmetij (84\% gospodarjev ima le praktične izkušnje; tabela 2), saj je možno dopolnilno dejavnost priglasiti le, če ima nosilec primerno izobrazbo. Za ustrezno usposobljenost ZK šteje (ZK, 2000, čl. 68, 18):

- najmanj poklicno kmetijsko izobrazbo ali

- opravljen preizkus znanja iz kmetijske dejavnosti po programu kmetijskih poklicnih ali srednjih šol s posebnim poudarkom na kmetijski dejavnosti, ki jo fizična oseba opravlja oz. ki jo namerava opravljati ali

- najmanj petletne delovne izkušnje na kmetiji ali v posamezni kmetijski dejavnosti in

- usposobljenost za opravljanje dopolnilne dejavnosti.

13 Vsaka kmetija posreduje naslov, nadmorsko višino kmetije, velikost kmetije, sezono odprtja, število sob/apartmajev; vrsto dejavnosti, obenem so na voljo tudi nekateri drugi koristni podatki (lega kmetije in značilnosti pokrajine, kulinarična ponudba, doživetja in možnosti za preživljanje prostega časa na kmetiji in v okolici, organizirane počitnice za otroke, dostop, vinska cesta, aktivnosti na kmetiji in v okolici). Od leta 1999 označuje omenjeno združenje kakovost na turističnih kmetijah z jabolki glede na obseg in kakovostno raven opremljenosti in storitev določene turistične kmetije (upoštevajo urejenost kmetije kot celote, urejenost okolja in zunanji videz kmetije, urejenost vseh zunanjih površin in površin, ki so namenjene gostom, urejenost kmečke hiše in drugih prostorov, ki so namenjeni gostom, kakovost hrane in pijače, možnosti za preživljanje prostega časa). 
Zatečeno stanje poskuša Ministrstvo za šolstvo, znanost in šport počasi izboljšati s spremembami, posodobitvami in prilagoditvami izobraževalnega programa srednjih strokovnih šol, kjer dijake poleg osnovnega poklica usposabljajo še za izvajanje ene od dopolnilnih dejavnosti (pridelava in predelava zdravilnih in aromatičnih zelišč, lesno pletarstvo, mizarstvo, čebelarstvo, ročna dela, šiviljski tečaji, tkanje na ročnih statvah, vzdrževanje kmetijske mehanizacije; http://www.s-scptuj.mb.edus.si/kmetijska/kmetdop.htm).

\section{Študija primera: kmetije v izbranih naseljih Kranjsko- Sorškega polja in Kamniškobistriške ravnine}

Raziskava je ugotavljala razširjenost in vrsto dopolnilnih dejavnosti na kmetijah (skupaj 237 kmetij: $217 \mathrm{v}$ ravninskem in $20 \mathrm{v}$ gričevnato-hribovitem obrobju) osrednjega, gospodarsko najbolj razvitega, za kmetijstvo najbolj primernega (relief, klima, prst), enostavno dostopnega in najgosteje poseljenega dela Slovenije (Ljubljanska kotlina: Kamniškobistriška ravan in Kranjsko-Sorško polje), leto uvedbe ter načrtovane dopolnilne dejavnosti.

Karta 1: Naselja preučevanega območja.

Map 1: Selected settlements of the case study area. 
Tabela 3: Razširjenost dopolnilnih dejavnosti in predvidene posodobitve na kmetijah preučevanega območja.

Tab. 3: Supplementary Activities on farms of case study area.

\begin{tabular}{|l|c|c|c|c|c|c|c|c|}
\hline \multirow{2}{*}{ NASELJE } & \multicolumn{3}{|c|}{ DOPOLNILNE DEJAVNOSTI } & \multicolumn{5}{c|}{ PREDVIDENE POSODOBITVE } \\
\cline { 2 - 9 } & DA & NE & NE VE & SKUPAJ & DA & NE & NE VE & SKUPAJ \\
\hline Crngrob & 2 & & & 2 & 2 & & & 2 \\
\hline Dobeno & 2 & 3 & & 5 & 1 & 4 & & 5 \\
\hline Dorfarje & 4 & 3 & & 7 & 2 & 5 & & 7 \\
\hline Dragomelj & 3 & 6 & & 9 & 2 & 6 & 1 & 9 \\
\hline Duplica & 1 & 1 & & 2 & & 1 & 1 & 2 \\
\hline Godešič & 1 & 9 & & 10 & 3 & 6 & 1 & 10 \\
\hline Ihan & 1 & 5 & & 6 & 2 & 4 & & 6 \\
\hline Komenda & & 7 & & 7 & 4 & & 3 & 7 \\
\hline Loka & 3 & 12 & & 15 & & 13 & 2 & 15 \\
\hline Moste & 5 & 14 & & 19 & 6 & 11 & 2 & 19 \\
\hline OIševek & 5 & 17 & & 22 & 7 & 13 & 2 & 22 \\
\hline Podgorje & 3 & 18 & & 21 & 4 & 16 & 1 & 21 \\
\hline Sp.Brnik & 6 & 25 & 2 & 33 & 11 & 17 & 5 & 33 \\
\hline Suha & & 7 & & 7 & 4 & 3 & & 7 \\
\hline Štef.Gora & 5 & 8 & & 13 & 4 & 9 & & 13 \\
\hline Voglje & 5 & 19 & & 24 & 7 & 17 & & 24 \\
\hline Zalog & 6 & 19 & & 25 & 5 & 17 & 3 & 25 \\
\hline Zg.Bitnje & 1 & 9 & & 10 & & 8 & 2 & 10 \\
\hline SKUPAJ-18 & 53 & 182 & 2 & 237 & 64 & 150 & 23 & 237 \\
\hline DELEŽ-18(\%) & 22.4 & 76.8 & 0.8 & 100 & 27.0 & 63.3 & 9.7 & 100 \\
\hline SKUPAJ-15 & 44 & 171 & 2 & 217 & 57 & 137 & 23 & 217 \\
\hline DELEŽ-15(\%) & 20.3 & 78.8 & 0.9 & 100 & 26.3 & 63.1 & 10.6 & 100 \\
\hline
\end{tabular}

Vir/Source: Anketa, 1999.

- Le petina anketiranih kmetij preučevanega območja že ima ali v bližnji prihodnosti načrtuje dopolnilno dejavnost na kmetiji. Za dopolnilne dejavnosti se večinoma odločajo mešane kmetije, $v$ podobnem obsegu tudi dopolnilne in mešane ${ }^{14}$.

14 Anketa je evidentirala tudi dopolnilne dejavnosti na kmetijsko neaktivnih posestvih in ostarelih kmetijah (prete_no gostilne), ki so jih lastniki uvedli _e pred desetletji. 
- Na kmetijah so razširjene:

1. dopolnilne dejavnosti, povezane s kmetovanjem: prevladuje kmečki turizem ( $v$ povezavi s konjerejo), gostinska dejavnost, zelenjadarstvo in vrtnarstvo, drevesnice, prodaja jajc, kisanje zelja in repe ter predelava mleka; 2. dopolnilne dejavnosti kot storitev: prevozništvo, servis kmetijskih strojev, mizarstvo, posek in obdelava lesa, avtomehanična delavnica, restavratorstvo, različne obrti, zimska služba.

- Nosilci dopolnilnih dejavnosti so mladi lastniki kmetij, ki so se pritoževali nad neživljenjskimi predpisi glede določenih dopolnilnih dejavnosti (npr. glede kmečkega turizma).

- Največ dopolnilnih dejavnosti na kmetiji so kmetje uvedli v zadnjih desetih letih, pred tem so prevladovale gostilne in nekatere tradicionalne dejavnosti (zimska služba, servis strojev, posek in obdelava lesa).

Dopolnilne dejavnosti predstavljajo dodaten vir dohodka le majhnemu deležu kmetij: za nekatere izmed njih imajo že pravo podjetniško funkcijo, pri večini pa imajo bolj funkcijo preživetja in ohranjanja kmetovanja. Dopolnilne dejavnosti na kmetijah niso novost, pač pa so se zaradi različnih vzrokov (kakovost življenja podeželskega prebivalstva, zahteve po doma pridelani hrani, varovanje virov in dediščine ipd.) hitreje razširile v zadnjem desetletju. Zaenkrat za večino kmetij še ne predstavljajo pomembnega vira dohodka.

\section{Geografski vidik dopolnilnih dejavnosti na kmetijah}

Z nekoliko razširjeno SWOT analizo želimo predstaviti geografski vidik dopolnilnih dejavnosti na kmetijah oz. na podeželju.

Tabela 4: Geografski vidik dopolnilnih dejavnosti na kmetiji.

Tab. 4: Geographical Aspect on Supplementary Activities on Farms. 


\begin{tabular}{|c|c|c|c|}
\hline PREDNOSTI & SLABOSTI & PRILOŽNOSTI & NEVARNOSTI \\
\hline $\begin{array}{l}\text { obstoječa tradicija in identiteta, } \\
\text { prenašanje znanj, vedenj in veščin na novo } \\
\text { generacijo }\end{array}$ & $\begin{array}{l}\text { pomanjkanje dobrih poznavalcev lokalne tradicije, } \\
\text { malo zainteresiranih, premalo odmevna reklamna } \\
\text { dejavnost turističnih promotorjev }\end{array}$ & $\begin{array}{l}\text { ohranjanje lokalne tradicije, identitete, } \\
\text { običajev, izdelkov, obrti }\end{array}$ & $\begin{array}{l}\text { ponudba se prilagodi okusu in zahtevam } \\
\text { turistov }\end{array}$ \\
\hline $\begin{array}{l}\text { uporaba starih lokalnih receptov, zagotovljena } \\
\text { poraba pridelkov/proizvodov }\end{array}$ & $\begin{array}{l}\text { omejena raznovrstnost pridelkov/proizvodov, } \\
\text { premajhna količina pridelkov/proizvodov }\end{array}$ & $\begin{array}{l}\text { uporaba doma pridelanih/predelanih pridelkov } \\
\text { in proizvodov (npr. na turistični kmetiji) }\end{array}$ & $\begin{array}{l}\text { otežkočen nadzor kakovosti } \\
\text { pridelkov/proizvodov }\end{array}$ \\
\hline $\begin{array}{l}\text { zaposlitev vsaj enega člana kmečkega } \\
\text { gospodarstva, vključitev starejših družinskih } \\
\text { članov }\end{array}$ & $\begin{array}{l}\text { večinoma slabo ali neustrezno izobražena } \\
\text { delovna sila }\end{array}$ & vključuje razpoložljive domače delovne sile & $\begin{array}{l}\text { preobremenjenost družinskih članov, } \\
\text { nevarnost opustitve primarne kmetijske } \\
\text { dejavnosti }\end{array}$ \\
\hline $\begin{array}{l}\text { nove investicije, doseganje paritetnega dohodka, } \\
\text { izboljšanje kakovosti żivljenja, večja socialna } \\
\text { varnost }\end{array}$ & $\begin{array}{l}\text { problem prepočasnega vračanja vloženih sredstev, } \\
\text { premalo finančne pomoči s strani države }\end{array}$ & $\begin{array}{l}\text { zagotovljen dotok denarja v družinski } \\
\text { proračun }\end{array}$ & $\begin{array}{l}\text { prevelika odvisnost od razmer na trgu } \\
\text { (nestabilne razmere, spreminjanje predpisov) }\end{array}$ \\
\hline $\begin{array}{l}\text { podobnost teh tehnologij s tradicionalnimi } \\
\text { oblikami, ohranjanje fiziognomije in } \\
\text { funkcionalnosti kmečkega doma, podpora } \\
\text { naložbam v kmečko gospodarstvo }\end{array}$ & $\begin{array}{l}\text { običajno visoka finančna vlaganja, časovno in } \\
\text { finančno zahtevno izobraževanje }\end{array}$ & $\begin{array}{l}\text { uvajanje sodobnejših, okolju prijaznih } \\
\text { tehnologij pridelave in predelave }\end{array}$ & $\begin{array}{l}\text { površna in nepremišljena porušitev, adaptacija } \\
\text { ali novogradnja, neprilagojenost novih } \\
\text { tehnik/tehnologij lokalnemu okolju }\end{array}$ \\
\hline $\begin{array}{l}\text { povečan intres za določen kraj/pokrajino, večja } \\
\text { prepoznavnost }\end{array}$ & $\begin{array}{l}\text { povečana prometna obremenitev (npr. pri turizmu } \\
\text { na kmetijah) }\end{array}$ & $\begin{array}{l}\text { pridobitev finančnih sredstev za izgradnjo } \\
\text { lokalne infrastrukture, izboljšanje kakovosti } \\
\text { żivljenja lokalne podeželjske skupnosti }\end{array}$ & $\begin{array}{l}\text { nenadzorovani in okolju škodljivi masovni } \\
\text { posegi, motnje ustaljene kmetijske proizvodnje }\end{array}$ \\
\hline $\begin{array}{l}\text { potrebno izkoristiti ugodna namenska posojila in } \\
\text { in neposredna lokalna, državna in EU sredstva }\end{array}$ & $\begin{array}{l}\text { velika finančna vlaganja, premalo razpoložljivih } \\
\text { sredstev }\end{array}$ & $\begin{array}{l}\text { premišljena in daljnovidna naložba } \\
\text { pridobljenih sredstev }\end{array}$ & $\begin{array}{l}\text { nepremišljena naložba, nevarnost } \\
\text { (kratkoročnih) spekulacij }\end{array}$ \\
\hline $\begin{array}{l}\text { zaradi kakovostnejše eko ponudbe prihaja več } \\
\text { zahtevnejših turistov/kupcev }\end{array}$ & $\begin{array}{l}\text { večja obremenitev okolja (poraba vode, energije, } \\
\text { več odpadkov, obremenitev kanalizacije) }\end{array}$ & $\begin{array}{l}\text { racionalna raba (ne)obnovljivih virov, zahteve } \\
\text { po izgradnji sodobnih infrastrukturnih } \\
\text { sistemov z višjimi okoljskimi standardi }\end{array}$ & $\begin{array}{l}\text { pomanjkanje interesa in denarja za tovrstne } \\
\text { naložbe }\end{array}$ \\
\hline mladi krepijo agrarno in demografsko strukturo & $\begin{array}{l}\text { malo možnosti za polno zaposlitev, neustrezna } \\
\text { izobrazba }\end{array}$ & $\begin{array}{l}\text { podpora mladim prevzemnikom kmetij, } \\
\text { zaustavljanje odhajanja (zlasti mladega) } \\
\text { prebivalstva }\end{array}$ & $\begin{array}{l}\text { slaba opremljenost prostora z dejavnostmi in } \\
\text { storitvami, ki jih zahtevajo oz. potrebujejo } \\
\text { mladi }\end{array}$ \\
\hline $\begin{array}{l}\text { dosedanja pridelava je večinoma } \\
\text { "bio"kakovostna, zagotovljen odkup }\end{array}$ & $\begin{array}{l}\text { premalo interesa s strani proizvajalcev, slaba } \\
\text { promocija, premajhna osveščenost potrošnikov }\end{array}$ & $\begin{array}{l}\text { prodaja izdelkov na eko tržnicah/sejmih/lokalih } \\
\text { prireditvah }\end{array}$ & $\begin{array}{l}\text { premajhen trg, nevarnost prevelike ponudbe } \\
\text { istovrstnih izdelkov, problemi pri registraciji } \\
\text { blagovne znamke }\end{array}$ \\
\hline $\begin{array}{l}\text { spodbujanje širjenja novosti, izkušnje dobrih } \\
\text { praks }\end{array}$ & velika finančna sredstva & inovativnost posameznikov & $\begin{array}{l}\text { neuspešnost investicije, okoljsko } \\
\text { obremenjujo }\end{array}$ \\
\hline složnost, pomoč, ekonomska upravičenost & slabe izkušnje iz preteklosti & $\begin{array}{l}\text { nujno povezovanje kmetov v vseh fazah dela } \\
\text { (proizvodnja, predelava, trženje, prodaja) }\end{array}$ & $\begin{array}{l}\text { otežkočeno usklajevanje raznolikih } \\
\text { interesov }\end{array}$ \\
\hline boljša prepoznavnost, povezana s kakovostjo & $\begin{array}{l}\text { velika finančna sredstva, poenotenje lokalnih } \\
\text { interesov }\end{array}$ & oblikovanje tržne/blagovne znamke & $\begin{array}{l}\text { nedovoljene izrabe tržne/blagovne } \\
\text { znamke }\end{array}$ \\
\hline krepitev odnosov, lokalne identitete & $\begin{array}{l}\text { težko preseči obstoječa/nastajajoča } \\
\text { nesoglasja }\end{array}$ & $\begin{array}{l}\text { sodelovanje celotne lokalne podeželjske } \\
\text { skupnosti }\end{array}$ & $\begin{array}{l}\text { stalni spori, neusklajeno delovanje, nezaupanje } \\
\text { do prihoda in vklju }\end{array}$ \\
\hline
\end{tabular}




\section{Zaključek}

Glede na trenutno razširjenost dopolnilnih dejavnosti v Sloveniji (le $5 \%$ vseh kmetij), predstavlja uvajanje le-teh le dodatni ukrep, ki bo služil kot trajna in dolgoročna podpora ukrepom, ki bodo pomagali izboljšati celotno agrarno strukturo v Sloveniji. Zato bi bil nujen kakovostnejši in skrbnejši nadzor nad finančnimi sredstvi, ki se bolj ali manj namensko porabljajo za dopolnilne dejavnosti (čeprav je potrebno izpostaviti, da je tovrstnih sredstev občutno premalo), in njihovimi dejanskimi ekonomskimi učinki ter socialnimi in prostorskimi posledicami razširjanja dopolnilnih dejavnosti.

Dopolnilne dejavnosti bi lahko zaradi svoje raznovrstnosti predstavljale velik razvojni potencial podeželja, vendar se izpostavlja vprašanje trga za tovrstne materialne proizvode in nematerialne storitve. Ali smo se Slovenci pripravljeni odreči tednu dopusta ob morju in ga preživeti na turističnih kmetijah? Analiza obiskovalcev turističnih kmetij v Sloveniji je pokazala, da gre večinoma za eno- do dvodnevne obiskovalce, ki imajo najmanj srednješolsko izobrazbo. Ali so na to pripravljeni tudi oblikovalci turistične ponudbe? Ali smo pripravljeni plačati do $20 \%$ več za mlečne in mesne proizvode, ki bodo nastali (z ustreznimi certifikati) v Sloveniji, namesto da bi kupili cenejše tuje blago (ne)jasnega porekla? Kako bo na zahteve po svobodnem pretoku trgovskih dobrin in pred zahtevo domačih proizvajalcev po zaščiti odgovorila država? Konec koncev - ali so na to pripravljeni kmetje? Sredstva Sapard bodo namreč dodeljena le gospodarjem, mlajšim od 40 let, ki bodo imeli najmanj poklicno izobrazbo.

V konceptu podjetniškega pristopa $\mathrm{k}$ razvoju podeželja dopolnilne dejavnosti lahko prehajajo $\mathrm{v}$ osnovne dejavnosti posameznikov/družin, osnovne $\mathrm{v}$ dopolnilne, ali pa se preprosto prepletajo in dopolnjujejo $v$ celovit proizvod konkretne podeželske skupnosti.

Po zgledih zahodnoevropskih držav se zaenkrat v Sloveniji veliko govori o dopolnilnih dejavnostih na kmetijah, s katerimi bi kmetje z dodatnim oplemenitenjem (predelavo) in neposredno prodajo svojih pridelkov vnovčili več svojega dela in znanja, o alternativnih proizvodnih programih v kmetijstvu, s katerimi bi zapolnili tržne niše, o ekološkem kmetovanju, ki naj bi z večjo kakovostjo pridelkov omogočilo doseči boljše cene, o kmečkem turizmu, ki naj omogoči večjo zaposlenost kmečkim družinam, gospodarsko izrabo prostih bivalnih zmogljivosti, neposredno prodajo pridelkov in kmetijske dejavnosti (npr. reja športnih konj), ki bi sicer ne bile gospodarsko zanimive, 
ali kompleksno oskrbo starejših občanov. Glasne so zahteve, da je potrebno zagotavljati čim več delovnih mest $v$ drugih sektorjih gospodarstva na podeželju, da bi odvečna delovna sila na kmetijah našla zaposlitev in tako lahko prispevala svoj delež v družinski proračun. S programi celostnega razvoja podeželja naj bi kmečkemu (in seveda drugemu podeželskemu) prebivalstvu omogočali enakovredno kakovost življenja. Ob poslušanju glasnih parol dobimo občutek, da je tovrstna razvojna usmeritev ena glavnih prioritet bodočega razvoja Slovenije. A na žalost pogled na dodeljena finančna sredstva ponuja drugačno zgodbo. Problematične so tudi nekatere neprilagodljive institucije. Taka usmeritev pa ne zagotavlja, da bi dopolnilne dejavnosti na kmetiji pomenile rešitev za slovensko kmetijstvo $v$ luči pristopanja evropskim integracijam; vprašanje je tudi, če so rešilni izhod v sili? Mogoče pa gre spet za slovensko posebnost: prepletanje tradicije, želje po inovativnosti in iskanju hitrejšega in zanesljivejšega zaslužka v miniaturni obliki.

\section{Summary}

Supplementary activities on farms represent a process that has been evident in Slovene rural areas for centuries, but it has had different forms, extend and role.

Taking into account the present extension of supplementary activities on farms in Slovenia (only $5 \%$ of all farms) their implementation represents only an additional measure in the process of agriculture reconstruction. But in a long run they will serve as a long-term support to the measures aimed in improvement of agricultural structure at whole. Therefore qualitative and detailed supervision of sector financial expenses is needed, and further more their actual economic effect, social and spatial consequences have to be monitored and evaluated.

We consider supplementary activities due to their diversity as a great development potential for rural areas, but the question of market arises (size, demand, competition of other EU countries).

But are we prepared to make this dream come true? There is much talk on supplementary activities and one could get the impression that they represent one of the top development priorities of future development in Slovenia. Therefore we also have to confront the real picture: deficit in 
financing at all stages. Some evidently non-adaptable institutions make another problem, too.

What about the farmers? Many of them still live in the middle of $19^{\text {th }}$ century (i.e. farm size) or in the former system. They have to change their overview on agriculture, accept the marketing approach and sustainable development orientation, new trade conditions, express their need for innovation.

Are Slovenia's citizens prepared to this? Are we prepared to say no to oneor two- week vacations at the seaside and spend vacations on farms or in rural areas? Analysis conducted on farms, dealing with tourism, showed typical structure of visitors: one- or two-days visitors with at least secondary education. What about tour operators? Are they willing to prepare new destinations? Is the average consumer prepared to pay $20 \%$ more for various qualitative agricultural products or will he/she follow the price only? Integration and common market of EU in agriculture- what about the state's policy?

Status Quo philosophy (read: practice) in the field of supplementary activities in Slovenia does not ensure their development as a redemption of Slovene agriculture/rural areas, but the question remains- will they play a rescue boat in the wave of EU integration process? Maybe- this is another example of Slovene originality: combination of tradition, limited willingness for innovation, search for the fastest and assured income, but everything in small-scale. Is this sustainable, long-term acceptable? There is an urgent need for supervised and stimulated approach based on reasonable local initiative and complex co-ordination. 


\section{Viri in literatura}

Popis kmetijskih gospodarstev v Republiki Sloveniji, junij 2000, 2000. Osnutek vprašalnika. SURS, Ljubljana, 9 str.

Statistične informacije, 2000, št. 34/2000. SURS, Ljubljana, str. 10, 11.

Statistični letopis Republike Slovenije 1999. Statistični urad Republike Slovenije, Ljubljana, str. 645.

Statistični letopis Republike Slovenije 2000. Statistični urad Republike Slovenije, Ljubljana, str. 679.

UL RS, št. 32/2001 (04.05.2001).

UL RS, št. 46/2001 (08.06.2001).

Zakon o kmetijstvu, 2000. Osnutek zakona z dne 29.02.2000. Ljubljana, 38 str.

Agricultural policy towards rural development, 1999. Poročilo Republike Slovenije za 30. konferenco FAO (12.-23.11.1999), Rim, 4 str.

Barbič, Kladnik, Kovačič, Rupena-Osolnik, Hribernik, 1984, Mešane kmetije kot dejavnik razvoja kmetijstva in podeželja. Biotehniška fakulteta, Ljubljana, str. 64-90.

Ilbery, B. (ed.), 1998, The Geography of Rural Change. Longman, UK, 267 str.

Izhodišča, sestavine in problemi celovitega razvoja podeželja v Sloveniji, 1995. Zbornik posveta. Biotehniška fakulteta et al., Ljubljana, 250 str.

Kladnik, D., 1999, Leksikon geografije podeželja. Inštitut za geografijo, Ljubljana, 318 str.

Klemenčič, V., 1991, Tendence spreminjanja slovenskega podeželja. GV 63. Ljubljana, 15 str.

Kovačič, M., 2000, Razvojno-tipološka členitev podeželja v Republiki Sloveniji. Biotehniška fakulteta, Oddelek za agronomijo, Inštitut za agrarno ekonomiko, Ljubljana, str. 112-114.

Kovačič, Udovč, Fabijan, Čebulj, Perpar, Kramarič, 2000: Zasnova strategije razvoja kmetijstva in dopolnilnih dejavnosti na območju MO Ljubljana. Biotehniška fakulteta, Oddelek za agronomijo, Inštitut za agrarno ekonomiko, Ljubljana,

Kovačič, M., 2000, Razvojne dileme slovenskega kmetijstva ob približevanju EU. 
Slovenija proti Združeni Evropi. Ljubljana, 7 str.

Malinen, Jussila, Hškkilš (ur.), 1993: Finlandīs National Rural Policy facing the Challenge of European Integration.University of Oulu, Oulu, 222 str.

Marušič, I., 2000, Trajnostno regionalno razvojno načrtovanje. Zbornik rezultatov projekta. Regionalni center za okolje za Srednjo in Vzhodno Evropo, Ljubljana, str. 50-57.

Potočnik, I., 2000: Družbenogeografske značilnosti kmetijstva v Ljubljanski kotlini (na izbranih primerih). Filozofska fakulteta, Oddelek za geografijo, Ljubljana, 209 str.

Verbič, D., 1999: Slovensko podeželje: katalog turističnih kmetij. Združenje turističnih kmetij Slovenije, Ljubljana, 200 str.

http://www.car.si/agronet/institu/kz_novo_mesto/predstav_obmocja.htm, citirano 10.07.2001.

http://www.uem-rs.si/slo/publikacije/cedaw/15.html),

citirano 16.07.2001.

http://www.s-scptuj.mb.edus.si/kmetijska/kmetdop.htm,

citirano 16.07.2001.

http://www.izit.si/muv/2001/predpisi/90.html,

citirano 10.07.2001.

http://www.nkbm.si/html/poslovanje/razpisi/ormoz_posojila.html,

citirano 10.07.2001.

http://www.sigov.si/zrs/kmet00/kmet00.doc,

citirano 16.07.2001. 